\title{
Linkage between Money and Prices: A Causality Analysis for Malaysia
}

\author{
Mohd Fahmi Ghazali \\ Labuan International School of Business and Finance \\ Universiti Malaysia Sabah, Labuan International Campus \\ Jalan Sg. Pagar, 87000 W.P. Labuan, Malaysia \\ Tel: 60-87-466-715 E-mail: mohdfahmi_ghazali@yahoo.com \\ Hanudin Amin \\ Labuan International School of Business and Finance \\ Universiti Malaysia Sabah, Labuan International Campus \\ Jalan Sg. Pagar, 87000 W.P. Labuan, Malaysia \\ Tel: 60-87-466-718 E-mail: hanudin@mailkal.ums.edu.my \\ Mohd Zulkifli Muhammad \\ Labuan International School of Business and Finance \\ Universiti Malaysia Sabah, Labuan International Campus \\ Jalan Sg. Pagar, 87000 W.P. Labuan, Malaysia \\ Tel: 60-87-460-498 E-mail: zulrider@yahoo.com \\ Siti Hajar Samsu \\ School of Business and Economics \\ Universiti Malaysia Sabah \\ Locked Bag 2073 \\ 88999 Kota Kinabalu, Sabah, Malaysia \\ Tel: 60-88-320-000 Ext. $1551 \quad$ E-mail: sitihajar@ums.edu.my
}

\begin{abstract}
The main purpose of this paper is to examine the relationship between money and prices in Malaysia. This research considers monthly data of money supply M1, M2 and M3 and consumer price index (CPI) from January 1974 to September 2006. The Johansen cointegration method suggests that there is a long-run equilibrium relationship between money supply with prices. Toda-Yamamoto causality tests find that there is uni-directional causality running from money supply to CPI. Therefore, the empirical evidence from Malaysia supports the quantity theorist's view.
\end{abstract}

Keywords: Causality, Money, Prices, Malaysia

\section{Introduction}

This paper investigates the relationship between money supply and prices in Malaysia using monthly data over the period January 1974 to September 2006. Nowadays, empirical analysis on money and prices relationship has received greater attention, as there is a move to assign the single objective to the central bank. Among likely candidates of monetary policy objective, price stability is the single most important objective. Assignment of price stability as the single objective of monetary policy hinges on the empirical strength of money-consumer price index $(C P I)$ relationship. If empirical result show a strong and robust relationship between money supply and $C P I$, then the central bank an opt for price stability as its single objective.

Over the past two decades, policy makers have become more aware of the social and economic cost of inflation and more concerned with a stable price level as a goal of economy policy. Price stability is desirable because a rise in price level (inflation) creates uncertainly in the economy, and that may hamper economy growth. Not only do public opinion surveys indicate that the public is very hostile to inflation, but also a growing body of evidence suggests that inflation leads to lower economic growth (Fisher, 1993). 
There is a strong positive correlation between changes in money supply and aggregate prices. The direction of causality, however, has long been a matter of controversy. The widely accepted quantity theory of money argues that inflation is caused by exogenous changes in the money supply. A minority 'structuralist' view holds that inflation, develops from pressures arising in economic growth in economies with institutional rigidities, particularly in agriculture and international transactions. Monetary and fiscal authorities choose to expand the money supply, ratifying the inflationary pressures, rather than face unemployment or disruptions in consumption and investment. Underdeveloped financial markets and a weakly independent central bank can contribute to the likelihood of money supply growth. Under this view, money supply expansion is a consequence of, and therefore caused by, structural inflation (Pinga and Nelson, 2001).

The motivation of this study is the need for a further empirical work analyzing the relations between money and prices in Malaysia to reassert that causality exist. More technically, this research applies the modified-Wald test (MWald) test approached by Toda and Yamamoto (1995) to reinvestigate the causal relations between money supply and price. In addition, this study will also use the most appropriate monetary target, $M 1, M 2$, and $M 3$ for curbing inflation and applied to a longer and more recent period.

The rest of the paper is organized as follows. In the next section, we review some empirical studies and the main findings. Section three gives a brief discussion about the data set used in the present paper and outlines the methodology employed. In section four we discusses the empirical results, while section five we provide concluding remarks.

\section{Literature review}

The direction of causality between money and prices have been tested in Malaysia over various periods of time. The results have yielded conflicting evidence. For example, Tan and Baharumshah (1999) has examined the dynamic causal chain among money (M1, M2 and M3), real output, interest rate and inflation in Malaysia using monthly data from 1975 to 1995. They found that price does Granger cause $M 2$ through short-run channel. In addition, the error correction model has provided evidence that real income, interest rate and price do jointly lead $M 2$ in the long run, and the real output, interest rate and $M 2$ do jointly cause price. The study, however, did directly not tell the causal relations between money and price rather than joining the other variables.

Masih and Masih (1998) investigated the causality between money (M1 and M2) and prices in four Southeast Asian developing countries, namely Thailand, Malaysia, Singapore, and the Philippines from January 1961 to April 1990. They found that money supply lead prices which are in agreement with the monetarist view.

Pinga and Nelson (2001), on the other hand, examined the relationship between money supply and aggregate prices for 26 countries, and found that no causal relationship between prices and money (M1 and M2) in Malaysia. They also found that aggregate prices cause money supply in Chile and Sri Lanka, which are in agreement with the structuralist view. Evidence of money supply exogeneity was found to be strongest in Kuwait, Paraguay, and the US. Most countries exhibited mixed evidence of money supply endogeneity, with bi-directional causation between money supply and aggregate prices a common result.

Using modified Wald test, Tang (2004) examined the causality between money (M2) and prices in Malaysia from 1970:Q1 to 1998:Q4. He found that there is a uni-directional causality running from money to prices, and it supports the monetarist view.

Research on other countries has found both bi-directional causality and uni-directional causality. Jones (1989) examined the causality between money and prices in the US over the period 1959:Q1 to 1986:Q2. The results, however, show feedback relationship between the measures of money growth (M1 and $M 2)$ and inflation (CPI and wholesale price index $(W P I)$ ). On the other hand, Darrat (1986) examined the direction of causation between money and prices for Morocco, Tunisia and Libya over the period 1960:Q1 and 1980:Q2. The results show a uni-directional causation running from money to prices without feedback for all the three countries concerned. Darrat (1986) concluded that the results support the monetarist view that money causes inflation.

Monetary Division, Research Department, Nepal Rastra Bank (2001) found that there is a feedback interaction in Nepal from 1975:Q3 through 1999:Q2. Recent study by Benbouziane and Benamar (2004) on the three Maghreb countries found that there was a uni-directional causation from money to prices in the case of Morocco and Tunisia, supports Darrat's (1986) finding. On the other hand, the results also show the apparent absence of causality between money and prices in the case of Algeria, which is not easy to explain.

\section{Data and methodology}

\subsection{Data}

In order to perform the causality analysis, we use monthly data for $M 1, M 2$, and $M 3$ (in millions of ringgit). The $C P I$ (in 2000 prices) is used as proxy for price. The data set was drawn for the period from January 1974 to September 2006, which comprises 393 observations in total. The variables are obtained from various issues of the International Financial 
Statistics (IFS) published by the International Monetary Fund (IMF) and transformed into natural logarithm scale prior to analysis.

\subsection{Johansen Cointegration Tests}

A preliminary issue regarding the methodological procedure is related to the fact that the data generating process for most of the economic series exhibits a unit root. Time series properties, namely order of integration and cointegration, have been examined by applying the full information multivariate procedure proposed by Johansen (1988).

The cointegration methodology basically characterizes the existence of a long-run relationship. According to Johansen (1988), a $p$-dimensional vector autoregression (VAR) of order $k$ [VAR $(k)]$ can be specified as follows:

$$
Z_{t}=d+\prod_{1} Z_{t-1}+\ldots+\prod_{k} Z_{t-k}+\omega_{t}(t=1 \ldots T)
$$

We can rewrite this expression as,

$$
\Delta Z_{t}=d+\prod_{k} Z_{t-k}+\sum_{i=1}^{k-1} \theta_{i} \Delta Z_{t-i}+\omega_{t}
$$

Here $\Delta$ is the first difference operator, $\Pi$ and $\theta$ are $p$-by-p matrices of unknown parameters and $\omega_{t}$ is a Gaussian error term. Long-run information about the relationship between money and prices in Malaysia is contained in the impact matrix $\Pi$. When the matrix $\prod$ has full column rank, it implies that all variables in $Z_{t}$ are stationary. When the matrix $\Pi$ has zero column rank, the expression is a first differenced VAR involving no long-run elements. If, however, the rank of $\Pi$ is intermediate meaning that $0<\operatorname{rank}(\Pi)=r<p$, there will be $r$ cointegrating vectors that make the linear combinations of $Z_{t}$ become stationary or integrated.

There are two Johansen cointegration tests. First, the maximum likelihood estimation procedure provides a likelihood ratio test, called a trace test, which evaluates the null hypothesis of, at most, $r$ cointegrating vectors versus the general null of $p$ cointegrating vectors. A second, likelihood ratio test is the maximum eigenvalue test, which evaluates the null hypothesis of $r$ cointegrating vectors against the alternative of $(r+1)$ cointegrating vectors.

\subsection{Granger Causality Tests based on Toda and Yamamoto levels VAR}

To examine the issue of causations, we have employed a modified version of the Granger causality test, which is robust for the cointegration features of the process. This procedure was suggested Toda and Yamamoto (1995) with the objective to overcome the problem of invalid asymptotic critical values when causality tests are performed in the presence of non-stationary series. Zapata and Rambaldi (1997) explained that the advantage of using the Toda-Yamamoto procedure is that in order to test Granger causality in the VAR framework, it is not necessary to pre-test the variables for the integration and cointegration properties, provided the maximal order of integration of the process does not exceed the true lag length of the VAR model. According to Toda and Yamamoto (1995), Toda-Yamamoto procedure however does not substitute the conventional unit roots and cointegration properties pre-testing in time series analysis. They are considered as complimentary to each other.

The Toda-Yamamoto procedure basically involves the estimation of an augmented VAR $\left(k+d_{\max }\right)$ model, where $k$ is the optimal lag length in the original VAR system, and $d_{\max }$ is the maximal order of integration of the variables in the VAR system. The Toda-Yamamoto procedure uses a modified-Wald test (MWald) test for zero restrictions on the parameters of the original VAR $(k)$ model. The remaining $d_{\max }$ autoregressive parameters are regarded as zeros and ignored in the VAR $(k)$ model. This test has an asymptotic chi-squared distribution with $k$ degrees of freedom in the limit when a VAR $\left(k+d_{\max }\right)$ is estimated. The dynamic causal relationship between prices and money supply would be as follows:

$$
\begin{aligned}
& L M_{t}=\alpha+\sum_{i=1}^{k+d} \beta_{i} L M_{t-i}+\sum_{j=1}^{l+d} \gamma_{j} L C P I_{t-j}+u_{t} \\
& L C P I_{t}=a+\sum_{i=1}^{m+d} b_{i} L C P I_{t-i}+\sum_{j=1}^{n+d} c_{j} L M_{t-j}+v_{t}
\end{aligned}
$$

Where $L M$ and $L C P I$ are, respectively, the logarithm of money supply (M1, M2 and M3) and of general price level, $t$ is time period, $k, l, m$, and $n$ is the optimal lag length, $d$ is the maximal order of integration of the series in the system and $u$ and $v$ are error terms that are assumed to be white noise. The initial lag lengths $k, l, m$ and $n$ are chosen using the Schwarz Information Criteria. However, the initial lag lengths are augmented with extra lag(s) depending on the likely order of integration (d) of the series $L M_{t}$ and $L C P I_{t}$. If $L M_{t}$ and $L C P I_{t}$ is likely to be I (1) (as it is with most macroeconomic data) 
then one extra lag is added to each variable in Equations (3) and (4). If both variables are assumed I(0), no extra lag is added in the equation, and the Toda Yamamoto test is equivalent to the Granger causality test. Wald tests are then used to test the direction of causality. For example, in Equation (3), the lags of $C P I_{t}$, excluding the extra lag added to capture maximum order of integration, are tested for their significance. If the null hypothesis that the lags are jointly equal to zero is accepted, then $C P I_{t}$ does not cause $M_{t}$. Testing for the joint significance of $M_{t}$, excluding the extra lag added, in Equation (4) allows tests for uni-directional or bi-directional causality.

\section{Estimation results}

The first stage involves establishing the order of integration using the Augmented Dickey-Fuller (ADF), with and without a deterministic trend. Table 1 presents the results of the unit root tests for the four variables, $M 1, M 2, M 3$ and $C P I$. The results indicate that all the variables are not stationary in their levels. On the other hand, all data are stationary at first difference and therefore indicating that all variables are I (1).

Table 1. Results of the Unit Root Tests

\begin{tabular}{|l|l|l|l|l|}
\hline \multirow{2}{*}{ Variables } & \multicolumn{2}{|l|}{ ADF Unit Root Tests at Level } & \multicolumn{2}{l|}{ ADF Unit Root Tests at First Different } \\
\cline { 2 - 5 } & $\tau_{\mu}$ & $\tau_{\tau}$ & $\tau_{\mu}$ & $\tau_{\tau}$ \\
\hline$L M 1$ & $-0.8949(16)$ & $-2.8132(16)$ & $-4.1927(15)^{* * *}$ & $-4.2306(15)^{* * *}$ \\
\hline$L M 2$ & $-1.3166(12)$ & $-2.6210(12)$ & $-3.4090(11)^{* *}$ & $-3.5702(11)^{* *}$ \\
\hline$L M 3$ & $-2.3671(16)$ & $-1.5282(16)$ & $-2.8800(15)^{* *}$ & $-3.6160(15)^{* *}$ \\
\hline$L C P I$ & $-1.8753(16)$ & $-1.4908(13)$ & $-3.8310(12)^{* * *}$ & $-3.9130(12)^{* *}$ \\
\hline
\end{tabular}

Notes: The null hypothesis is that the series is non-stationary, or contains a unit root. The rejection of the null hypothesis for ADF tests is based on the MacKinnon critical values. Values in parentheses are optimal lag lengths. $\tau_{\mu}$ and $\tau_{\tau}$ are constant and trend and constant, respectively. Asterisk $(* * *)$ and $(* *)$ denotes that a test statistic is significant at the $1 \%$ and $5 \%$ significance level, respectively.

Given the variables are I(1), the cointegration hypothesis between the variables is examined using the methodology developed in Johansen (1991) in order to specify the long-run relationship between the variables. The results of the cointegration tests are reported in Table 2. The null hypothesis of no cointegrating vector $(r=0)$ are rejected. Thus, the money supply $(M 1, M 2$ and $M 3)$ and the price level $(C P I)$ are cointegrated, indicated that there is a long-run relationship.

Table 2 . Testing for Bivariate Cointegration

\begin{tabular}{|l|l|l|l|l|l|l|l|}
\hline$H_{0}$ & $H_{l}$ & Eigenvalue & Trace Statistics & $\begin{array}{l}5 \% \text { Critical } \\
\text { Value }\end{array}$ & $\begin{array}{l}\text { Max-Eigen } \\
\text { Statistics }\end{array}$ & $\begin{array}{l}5 \% \text { Critical } \\
\text { Value }\end{array}$ & VAR \\
\hline LMI-LCPI \\
\hline$r=0$ & $r=1$ & 0.2150 & $98.2382^{* * *}$ & 19.96 & $94.3903^{* * *}$ & 15.67 & 2 \\
\hline$r \leq 2$ & $r=2$ & 0.0098 & 3.8479 & 9.24 & 3.8479 & 9.24 & \\
\hline$L M 2-L C P I$ \\
\hline$r=0$ & $r=1$ & 0.2184 & $99.7122^{* * *}$ & 19.96 & $96.0781^{* * *}$ & 15.67 & 2 \\
\hline$r \leq 2$ & $r=2$ & 0.0093 & 3.6341 & 9.24 & 3.6341 & 9.24 & \\
\hline$L M 3-L C P I$ &
\end{tabular}

Notes: VAR is order of the variance. ${ }^{* * *}$ denotes statistically significant at the $1 \%$ level. $H_{0}$ and $H_{l}$ denote the null and alternative hypothesis respectively and $r$ denotes the number of cointegrating vectors.

The Toda-Yamamoto causality test results are presented in Table 3. Since all the variables are in levels, the results provide information about the long-run causal relationships among non-stationary variables in the system. The results indicate that the null hypothesis that $C P I$ do not Granger cause $M 1, M 2$ and $M 3$ cannot be rejected. These suggest that the money supply does not respond to lagged changes in $C P I$ in the system. On the other hand, the hypothesis that money supply do not Granger causes $C P I$ can be rejected at the 1 percent significance level for $M 1$ and $M 3$ and 5 percent significant level for $M 2$. These indicate that there is only a uni-directional causality running from money supply to $C P I$ in the case of the Malaysia, but not the reverse. Therefore, the empirical evidence from Malaysia supports the quantity theorist's view. 
Table 3. Test of Causality, Toda-Yamamoto Approach

\begin{tabular}{|c|c|c|c|c|c|}
\hline \multirow{2}{*}{$\begin{array}{l}\text { Dependent } \\
\text { Variables }\end{array}$} & \multirow{2}{*}{$\begin{array}{l}\text { Independent } \\
\text { Variables }\end{array}$} & \multirow{2}{*}{$\begin{array}{l}\text { Lag } \\
\text { Structure }\end{array}$} & \multirow{2}{*}{ VAR Order } & \multicolumn{2}{|c|}{$\begin{array}{l}\text { Joint Test of Zero Restrictions of Variables } \\
\text { Added in Column } 2\end{array}$} \\
\hline & & & & MWald statistics & $p$-values \\
\hline \multicolumn{6}{|l|}{$L M 1-L C P I$} \\
\hline$L M 1$ & $L C P I$ & 1 & (2) & 0.0991 & 0.7530 \\
\hline$L C P I$ & $L M 1$ & 4 & (5) & $4.9200 * * *$ & 0.0007 \\
\hline \multicolumn{6}{|l|}{$L M 2-L C P I$} \\
\hline$L M 2$ & $L C P I$ & 1 & (2) & 1.7906 & 0.1816 \\
\hline$L C P I$ & $L M 2$ & 2 & (3) & $4.4023^{* *}$ & 0.0129 \\
\hline \multicolumn{6}{|l|}{$L M 3-L C P I$} \\
\hline LM3 & $L C P I$ & 2 & (3) & 2.1878 & 0.1136 \\
\hline$L C P I$ & $L M 3$ & 2 & (3) & $4.8836^{* * *}$ & 0.0080 \\
\hline
\end{tabular}

Notes: The $[\mathrm{k}+\mathrm{d}(\max )]$ th order level VAR was estimated with $\mathrm{d}(\max )=1$ since the order of integration is 1 . The lag length selection was based on Schwarz criterion test results (not reported in this paper). ${ }^{* * *}$ and ${ }^{* *}$ denotes statistically significant at the $1 \%$ and $5 \%$ level respectively.

\section{Conclusions}

This paper examined empirically the relationship between prices and money for Malaysia. We employed monthly data and applied cointegration using the Johansen approach and application of the Toda-Yamamoto causality approach to study the money and prices interaction. Using Johansen cointegration approach, our results show long-run association between prices and money, in line with previous research in other countries (see for example Benbouziane and Benamar (2004)). This mean that prices and money move together in the long-run. Using the powerful causality testing procedure developed by Toda and Yamamoto (1995), we found evidence of a uni-directional link from money to prices without significant feedback. This tends to support the quantity theorist's view that the causal relation between money and prices is from the former to the latter, in line with Masih and Masih's (1998) and Tang's (2004) work.

Thus, the monetary authorities can consider control of the money supply (M1, M2, and M3) to influence and control inflation. This is well known that the objective of Malaysian monetary policy is to maintain price stability in the form of low inflation in order to create a stable environment for sustainable economic growth. As suggested by monetarists, this can be best achieved by maintaining a steady rate of growth of the money supply, roughly corresponding to the long-run growth of the real output in order to achieve price stability and economic disturbances.

This study also suggests that the monetary policy should be conducted with care. Money supply can cause domestic price, and the latter variable plays an important role in determining Malaysia's import demand in the long run. An increase in domestic price might make imported goods become cheaper. Consequently, it might deteriorate the Malaysia external balance because of increasing demand on imported goods.

The above results provide evidence support the quantity theorist's view that postulate a uni-directional causation that runs from monetary aggregates to prices. We, however, suggest that the significant of our results could possibly be improved upon by applying a control variable to avoid possible bias of using bivariate framework in causality analysis as highligted by Al-Yousif (1999), that bivariate framework is potentially misspecified and maybe flawed due to the ommission-of-variable phenomenon. Thus, we suggest by adding domestic real activity and/or real exchange rate into the bivariate VAR framework between money and price.

\section{References}

Al-Yousif, Y. K. (1999). On the Role of Exports in the Economic Growth of Malaysia: A Multivariate Analysis. International Economic Journal, 13, 67-75.

Benbouziane, M. \& Benamar, A. (2004). The Relationship between Money and Prices in the Maghreb Countries: A Cointegration Analysis, The $11^{\text {th }}$ Annual Conference of the Economic Research Forum (ERF) Beirut - Lebanon December 16-28, 2004.

Brillembourg, A. \& Khan, M. S. (1979). The Relationship between Money, Income and Prices: Has Money Mattered Historically. Journal of Money, Credit and Banking, 11, 358-365.

Darrat, A. F. (1986). Money, Inflation and Causality in the North African Countries: An Empirical Investigation. Journal of Macroeconomics, 8, 87-103. 
Fisher, S. (1993). The Role of Macroeconomic Factors in Growth. Journal of Monetary Economics, 32, $485-512$.

Johansen, S. (1988). Statistical Analysis of Cointegration Vectors. Journal of Economic Dynamics and Control, 12 (2/3), 231-254.

Johansen, S. (1991). Estimation and Hypothesis Testing of Cointegration Vectors in Gaussian Vector Autoregressive Models. Econometrica, 59 (6), 1551-1580.

Jones, J. D. (1989). A Comparison of Lag-Length Selection Techniques in Tests of Granger Causality between Money Growth and Inflation: Evidence for the US, 1959-86. Applied Economics, 21 (6), 809-822.

Jones, J. D. \& Uri, N. (1987). Money, Inflation and Causality (Another Look at the Empirical Evidence for the USA, 1953-84. Applied Economics, 19 (5), 619-634.

Masih, A. M. M. \& Masih, R. (1998). Does Money Cause Prices, or the Other Way Around? Multi-Country Econometric Evidence Including Error-Correction Modelling From South-East Asia. Journal of Economic Studies, 25 (3), $138-160$.

Monetary Division, Research Department \& Nepal Rastra Bank (2001). Money and Price Relationship in Nepal: A Revisit. Economic Review: Occasional Paper, 13, 50-65.

Pinga, V. E. B. \& Nelson, G. C. (2001). Money, Prices and Causality: Monetarist versus Structuralist Explanations Using Pooled Country Evidence. Applied Economics, 33 (10), 1271-1281.

Tan, H. B. \& Baharumshah, A. Z. (1999). Dynamic Causal Chain of Money, Output, Interest Rate and Prices in Malaysia: Evidence Based on Vector Error-Correction Modeling Analysis. International Economic Journal, 13 (1), $103-120$.

Tang, T-C. (2004). Causality between Money and Price in Malaysia: A Revisit. Labuan Bulletin of International Business \& Finance, 2 (1), 71-81.

Toda, H. Y. \& Yamamoto, T. (1995). Statistical Inference in Vector Autoregressions With Posibbly Integrated Processes. Journal of Econometrics, 66 (1/2), 225-250.

Turnovsky, S. J. \& Wohar, M. E. (1984). Monetarism and the Aggregate Economy: Some Long Run Evidence. Review of Economics and Statistics, 66 (4), 619-629.

Zapata, H. O. \& Rambaldi, A. N. (1997). Monte Carlo Evidence on Cointegration and Causation. Oxford Bulletin of Economics and Statistics, 52 (2), 285-298. 